\title{
IAMJ
}

INTERNATIONAL

AYURVEDIC

MEDICAL JOURNAL

\section{A REVIEW ON VANASURANA GHRTA IN THE MANAGEMENT OF ARSHAS}

\section{$\underline{\text { Najiya A M}} * \underline{\text { Surej Subash}}^{2}, \underline{\text { Shyam Vinayan }}^{3}$}

${ }^{1}$ PG Scholar, Dept. of P.G Studies in Kayachikitsa, P.N.N.M. Ayurveda Medical College, Cheruthuruthy, Kerala, India

${ }^{2}$ Associate Professor, Dept. of P.G Studies in Kayachikitsa, P.N.N.M. Ayurveda Medical College, Cheruthuruthy, Kerala, India

${ }^{3}$ Associate Professor, Dept. of PG Studies in Shalya tantra, Amrita School of Ayurveda, Amrita Vishwa Vidyapeetham, Kollam, Kerala, India

Corresponding Author:drnajiyashafi@gmail.com

\section{https://doi.org/10.46607/iami2709082021}

(Published Online: August 2021)

Open Access

(C) International Ayurvedic Medical Journal, India 2021

Article Received:15/07//2021 - Peer Reviewed:17/07/2021 - Accepted for Publication:18/07/2021

\section{Check for updates}

\begin{abstract}
Arshas is one among many diseases which are most unkind towards mankind. The incidence of Arshas increases with advancing age and at least $50 \%$ of people over the age of 50 years have some degree of hemorrhoidal symptoms. Hemorrhoids are the dilated veins in the anal canal in the subepithelial region formed by radicals of the superior, middle, and inferior rectal vein ${ }^{[1]}$. In this modern era the improper diet habits, junk food intake, inhibition of natural urges and mental strain makes one susceptible to this disease. Acharya Sushrutha while detailing the treatment principles of Arshas has categorized it as Bheshajasadhya, Kshara Karma Sadhya, Agnikarmasadhya and shastra karma sadhya ${ }^{[2]}$. Surgical treatments though commonly being practised are very painful and hence will put the patients into more agony. Despite putting the patient into such a state there are high chances of recurrence of the condition. Hence there is a need for very effective as well as less/non-agonizing treatment for Arshas. Vansurana Ghrta is an unexplored formulation that is mentioned in ChikitsaManjari ${ }^{[3]}$. The main ingredient Vanasurana is considered as Agryoushada for Arshas in Kaiyyadevanighandu.
\end{abstract}

Keywords: Arshas, Vanasurana ghrta 


\section{INTRODUCTION}

Ayurveda is the most rational and time tested among the ancient systems of medicine. This science of life aims at alleviation of diseases as well as maintenance and promotion of good health. Ayurveda is based upon trisutra- hetu, linga and oushada amongst which oushada plays an important role in chikitsa. Arshas is mentioned as one among the ashtamahagada which is caused due by the impaired agni of the body. Nasa, netra, karna, and guda are the normal sites of Arshas. Gudapradesha which also happens to be a sadhyopranahara marmais the most common site for the same ${ }^{[4]}$. Being located near a marma, its management requires utmost care. Arshas though not a life-threatening condition can cause a lot of complications and troubles if not treated in its early stages. The incidence of anorectal disorder is progressively increasing in society, and it can be seen at any age and in both genders equally. It is estimated that 50$85 \%$ of people around the world have hemorrhoids and in India, $75 \%$ population is affected. A few studies indicate that a higher incidence was found in patients belonging to the age group between 20-39yrs $(55 \%)$ of both gender. The clinical symptoms observed are bleeding per rectum and mass per rectum in $85 \%$ of patients, Pain during defecation in $77.5 \%$, soiling of clothes observed in $22.5 \%$ \& history of pruritus in $12.5 \%{ }^{[5]}$.

According to Acharya Susrutha, the management of Arshas includes 4 methods like bheshaja, kshara,agni and sastra ${ }^{[6]}$. Among the four methods, bheshaja (medicine) is preferred and adopted over the other three especially in achirakala, alpa dosha linga, alpa upadrava and adrsya Arhsas ${ }^{[7] .}$ Vanasurana ghrtam is a medicinal preparation prescribed in Chikitsa Manjari-Arsho chikitsaprakaranam. It is a ghee preparation where panchakola is used as kalka and Vanasurana kashayam along with takra as drava dravya ${ }^{[3]}$. Vanasurana (Amorphophallus paeonifolius) is a perennial herb, which has properties such as ushna virya, kapha vatahara, arshoghna, and deepana pachana ${ }^{[8]}$. Panchakola the combination of 5 herbs together has deepana pachana properties. Takram is considered as agroushadam for arshas irrespective of any season ${ }^{[9]}$. Ghrtha in general is pitta shamana, madhura rasa, vrana shodhana, ropana and above all has a unique property samskaranuvarthanam. A drug which is Arshohara, that can retain the agni, safe, and easily administrable and available is required. The drugs used in the preparation are easily available in the market and is very much useful in Arshas.

\section{Materials And Methods:}

\section{Ingredients:}

Table no: 1

\begin{tabular}{|l|l|l|l|}
\hline DRUG & BOTANICAL NAME & FAMILY & PARTS USED \\
\hline Vanasurana & Amorphophallus paeonifolius & Araceae & Rhizome \\
\hline Pippali & Piper longum & Piperaceae & Fruit \\
\hline Pippali moola & Piper longum & Piperaceae & Root \\
\hline Cavya & Piper chaba & Piperaceae & Root \\
\hline Chitraka & Plumbago zeylanica & Plumbaginaceae & Root \\
\hline Zingiber Officinale & Zingiberacae & Rhizome \\
\hline
\end{tabular}

Materials required:

Kalka: Panchakola:

1) Pippali

2) Pippali Moola

3) Chavya
$125 \mathrm{gm}$
4) Chitraka

5) Nagaram

Dravadravya:

Vanasurana kashaya- 2L

Takram-2L

Ghrtam - 1L 


\section{Method of preparation:}

$125 \mathrm{gm}$ of panchakola is taken as kalka which is mixed with 2L Vanasurana kashaya \& 1L ghrtam. This mixture is boiled until mridupaka is attained. on attaining mridupaka $2 \mathrm{~L}$ takram is added to it and boiled again, till madhyama paka is attained. It is further filtered to obtain Vanasurana ghrtam.
According to Ayurveda classic, usually purification of Vanasurana is done by immersing it in amla dravya like takram, jambeera rasa, churnodaka etc. But Sodhana was not done in the preparation of Vanasurana ghrtha, as it may reduce the potency of the drug. Also, the medium of preparation of the drug being takra and ghrtha helps to reduce the irritability of the drug.

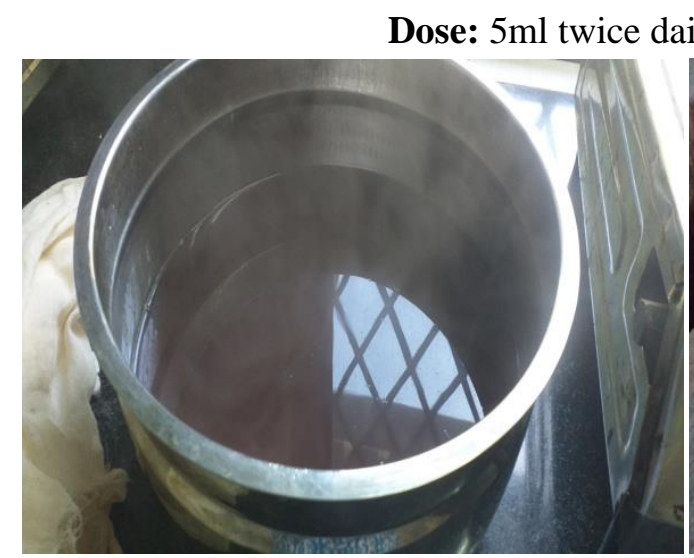

Photo 1: Vanasurana kashaya

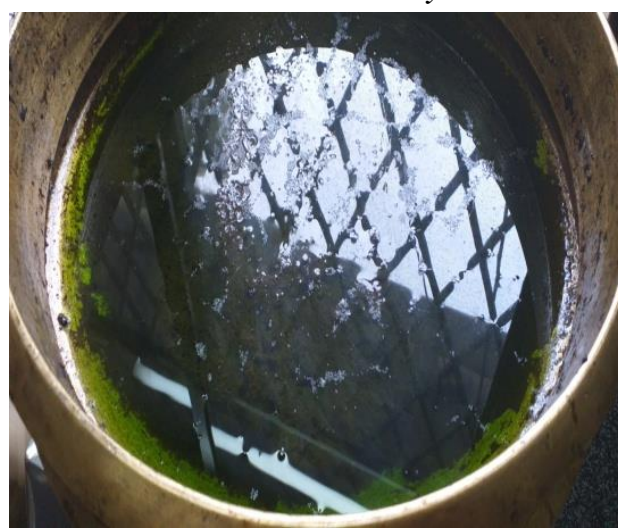

Photo 3: Mrdu paka

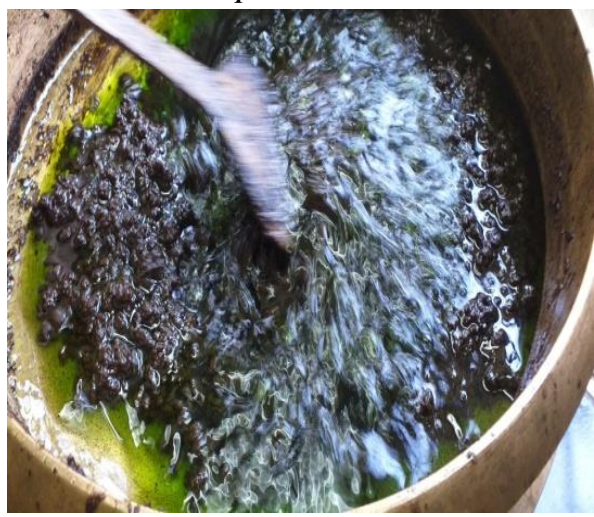

Photo 5: Madhyama paka

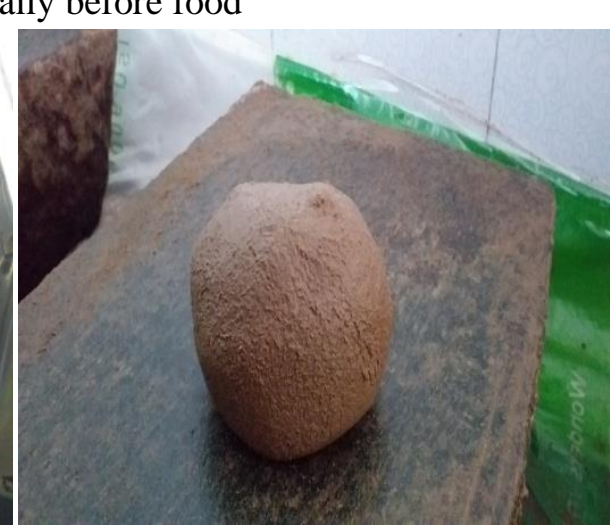

Photo 2: Panchakola kalka

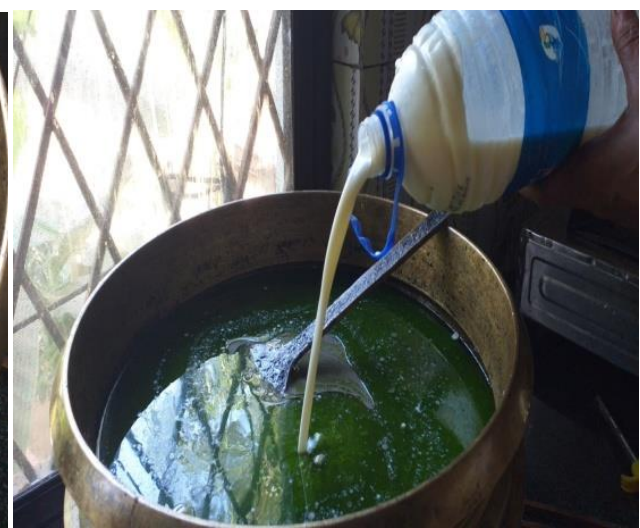

Photo 4: Addition of takra

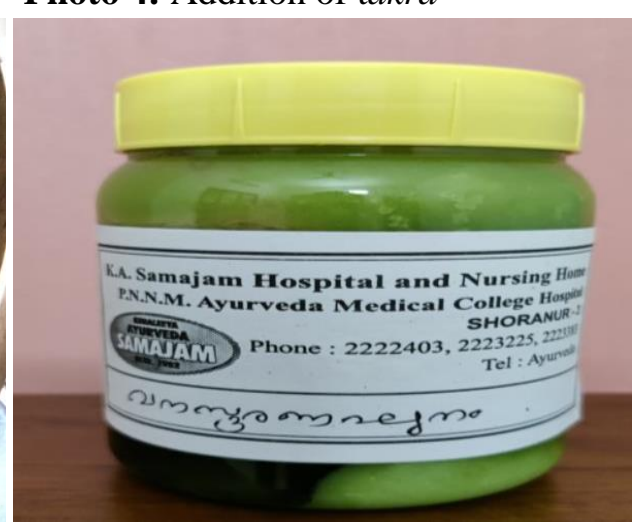

Photo 6: Vanasurana ghrta 


\section{DISCUSSION}

Arshas is a very common anorectal disorder, mainly caused by mandagni. It is defined as "arivat prana shrunothi hinasthi iti arsha" meaning that which tortures the diseased like an enemy ${ }^{[10]}$. It is mainly of two types- shushka Arsha and ardhra Arshas. It mainly presents with complaints such as protrusion of mass, constipation, pain during defecation, itching, bleeding per rectum and soiling of underclothes etc. Acharyas have advised to use drugs and foods which are vatanulomana and agni deepana when treating a patient with Arshas ${ }^{[11]}$. So, to prescribe the pathya and apathya as well as to design the treatments, these factors also have to be considered. Vanasurana ghrta is a formulation with Vanasurana as kashaya, panchakola churna as kalka and takra as dravadravya.The drug Vanasurana being katu kashaya in rasa, laghu - ruksha - tikshna in guna, ushna in virya and katu in vipaka works as an excellent kapha vataghna dravya. It is included in sakavarga as per Susrutha samhitha and Caraka samhita. Vanasurana has deepana pachana guna and hence it can be considered as an amadoshahara dravya and it possesses arshoghna karma also. Hence Vanasurana will be beneficial in Arshas and is selected here as the main ingredient of the formulation. There are multiple formulations with Surana which are available in the market for the management of Arshas. The tubers of the amorphophallus plant contain a polysaccharide Glucomannan, a water-soluble fibre content that has been reported with good gastro-kinetic effect and anti-inflammatory action. Panchakola includes pippali, pippalimula, cavya,chitraka and nagara. Most of the ingredients have katu rasa with laghu, snigdha and tikshna guna,ushna virya and kapha vata samaka property. The churna of panchakola is used as kalka in this ghrtha preparation. Hence, the anticipated actions of the preparation are deepana, pacana, vatanulomana, shulaghna, vrsya and rasayana.

Takra has madhura, amla and kashaya rasa, usnavirya and madhuravipaka. It is considered the agroushada for all types of Arshas. In Vanasurana ghrta formulations, takra is used as drava dravya. Takra using its different gunas acts as tridoshshamak (it decreases kapha, vata and do not allow pitta to aggravate). Due to this specific property, it is very useful in patients suffering from agni vikruti (abnormal conditions of digestive fire) having different kinds of dosha dushti (abnormal conditions of dosha) and having different kinds of prakuti (Constitution). Hence takra is an important component in treating the patients suffering from the diseases related to $a g$ ni. According to Acharya Caraka, takra is very useful in vata - kaphapradhana (aggravated conditions of vata \& kapha) Arsha. He has further stated that there is no other medicine on vata-kapha pradhana Arsha than that of takra. Ghrta is best among all sneha dravyas due to their samskaranuvarthi guna. It is madhura rasa, madhura vipaka and sheeta veerya. It has vatanulomana property also.

\section{CONCLUSION}

Ayurveda is known for its simple, preventive, curative, and holistic approach. Various types of principles of management like bheshaja, agni karma, kshara karma and sastra karma are indicated for the management of Arshas. Among these modes of treatment, bheshaja gives relief to the patient without fear of any complication. The best treatment for the management of Arshas would be a drug combination which comprises of an Arshoghna drug, an agnideepaka drug and an anulomaka dravya along with nidana parivarjana. All the Acharyas have emphasized the importance of takra in the treatment of Arshoroga.Ghrtha is pitta samaka, agni deepaka, madhura vipaka, sheeta veerya, vatanulomana and has samskaranuvarthana guna. A drug with these essential qualities is required for the treatment of $\mathrm{Ar}$ shas.

\section{REFERENCES}

1. Shenoy K Rajagopal NA. Manipal Manual of Surgery. Newdelhi: CBS Publishers and Distributors; 2010. Anorectal disease page 627.

2. Susruta. Illustrared Susruta Samhita. Reprint edition (Murthy KRS. English trans) Varanasi: Chaukhambha Orientalia; 2010. Arso chikitsa page 77. 
3. Chikitsa Manjari Namboothiri S. Alappuzha: Vidyarambha Publishers; 2011. Arsorogachikitsa. page 174.

4. Susrutha. Pratyekamarma Nirdesam Sareeram. In: Vaidya Jadavji Trikamji Acharya, editor. Sushruta Samhita. Varanasi: Chaukhamba Surbharati Prakashan; 2017. p 373-6/25.

5. Prevalence of haemorrhoids. http://ijsurgery.com>article accessed on 23.4.19

6. Susruta. Illustrared Susruta Samhita. Reprint edition (Murthy KRS. English trans) Varanasi: Chaukhambha Orientalia; 2010. Arso chikitsa page 76.

7. Susruta. Illustrared Susruta Samhita. Reprint edition (Murthy KRS. English trans) Varanasi: Chaukhambha Orientalia; 2010. Arso chikitsa page 77.

8. Sastry JL. Dravyaguna Vinjana. Varanasi: Chaukhambha Orientalia; 2010. Suran page 1019.

9. Vagbhata arshachikitsa Prakaraka B H. Astanghahridaya composed by vagbhata: with the commentaries (sarvanghasundara) of Arunadhata and (Ayurveda rasayana) of Hemadri. Tenth edition, Varanasi: choukamba orientalia;2011. Chikitsasthana p 644

10. Vagbhata arshaonidana Prakaraka B H. Astanghahridaya composed by vagbhata: with the commentaries (sarvanghasundara) of Arunadhata and (Ayurveda rasayana) of Hemadri. Tenthedition, Varanasi: choukambaorientalia;2011. Nidanasthana $\mathrm{p} 490$

11. Vagbhata arshachikitsa Prakaraka B H. Astanghahridaya composed by vagbhata: with the commentaries (sarvanghasundara) of Arunadhata and (Ayurveda rasayana) of Hemadri. Tenth edition, Varanasi: choukamba orientalia;2011. Chikitsasthana p 645

\section{Source of Support: Nil}

\section{Conflict of Interest: None Declared}

How to cite this URL: Najiya A $M$ et al: A Review On Vanasurana Ghrta In The Management Of Arshas. International Ayurvedic Medical Journal \{online\} 2021 \{cited August 2021\} Available from: http://www.iamj.in/posts/images/upload/1768_1772.pdf 